\title{
Pengaruh Pemahaman Hidup Kudus Menurut 1 Tesalonika 4:1-8 terhadap Perilaku Seksual Pemuda Remaja di GPdI Wilayah Sentani Timur Tengah
}

\author{
Priskila de Fretes ${ }^{1}$, Zulkisar Pardede ${ }^{2 \wedge}$ \\ ${ }_{1}^{1}$ Gereja Pantekosta di Indoensia Keerom Barat, Papua \\ 1,2 Pasccasarjana Sekolah Tinggi Alkitab Jember, Jawa Timur \\ *zulkisar@gmail.com
}

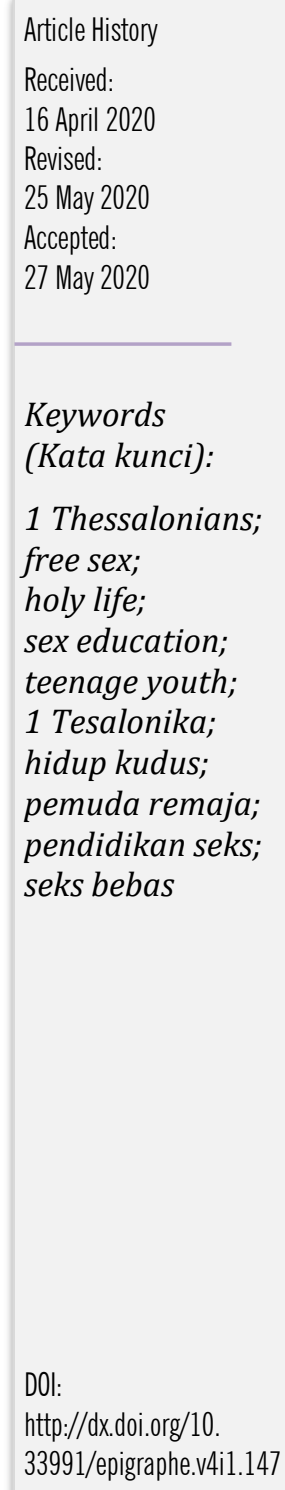

\begin{abstract}
This study aimed to determine whether there is an influence of the understanding of holy life according to 1 Thessalonians 4: 1-8 on the sexual behavior of GPdI youth/teenagers in the Sentani Timur Tengah Region; which dimensions affected the understanding of holy life according to 1 Thessalonians 4:1-8 on youth/ teenagers sexual behavior, and found out which background factors have the most influenced on sexual behavior in youth/teenagers in GPdI Sentani Timur Selatan Region. In this study, the population was youth/teenagers in the GPdI Sentani Timur Selatan Region totaling 123 people. This research used a quantitative (positivist) approach. The research method used was a quantitative research design with an explanatory-confirmatory method. Simple linear regression test results are $Y=-47,727+0.864 X$. In conclusion, the understanding of the holy life according to 1 Thessalonians 4: 1-8 has a positive effect on the sexual behavior of GPdI youth/youth in Sentani Timur Selatan (Y), with the dimension of "acceptance of God's presence" as the most dominant.
\end{abstract}

\begin{abstract}
Abstrak
Penelitian ini bertujuan untuk mengetahui apakah ada pengaruh pemahaman hidup kudus menurut 1 Tesalonika 4: 1-8 terhadap perilaku seksual pemuda/remaja GPdI di Wilayah Sentani Timur Tengah; dimensi manakah yang paling dominan memengaruhi pemahaman hidup kudus menurut 1 Tesalonika 4: 1-8, dan untuk mengetahui faktor latar belakang manakah yang paling berpengaruh terhadap perilaku seksual pada pemuda/remaja di GPdI Wilayah Sentani Timur Tengah. Dalam penelitian ini yang menjadi populasi adalah pemuda/remaja di GPdI Wilayah Sentani Timur Tengah yang berjumlah 123 orang. Penelitian ini menggunakan pendekatan kuantitatif (positivis). Metode penelitian yang digunakan adalah rancangan penelitian kuantitatif dengan metode eksplanatori-konfirmatori. Hasil uji regresi linear sederhana adalah $\mathrm{Y}=-47,727$ + 0,864X. Kesimpulannya, pemahaman hidup kudus menurut 1 Tesalonika 4:1-8 berpengaruh positif terhadap perilaku seksual pemuda/remaja GPdI di Sentani Timur Tengah (Y), dengan dimensi "penerimaan akan kehadiran Allah" sebagai yang paling dominan.
\end{abstract}




\section{Pendahuluan}

Masa muda adalah masa transisi seorang manusia dari masa kanak-kanak menuju masa dewasa. Waktu di mana seseorang memiliki perkembangan yang pesat akan pemikiran yang abstrak, penemuan identitas diri secara psikologis dan keinginan untuk dapat hidup mandiri. Salah satunya adalah pemuda dan remaja suka melakukan eksplorasi yang ditandai dengan memperluas hubungan antar pribadi, berkomunikasi secara lebih dewasa, memperoleh peranan sosial, menerima keadaan tubuhnya dan menggunakan secara efektif, memperoleh kebebasan emosional dari orang tua, menca-pai kepastian akan kebebasan dan kemampuan berdiri sendiri, memiliki dan mempersiapkan diri untuk suatu pekerjaan, mempersiapkan diri untuk perkawinan dan kehidupan berkeluarga dan mengembangkan serta membentuk konsep-konsep moral. ${ }^{1}$ Keadaan di atas membawa dampak yang signifikan dalam kehidupan pemuda dan remaja, di antaranya keterlibatan kepada hal-hal yang menarik secara duniawi.

Salah satu perilaku pemuda remaja yang terikat dengan keduniawian adalah yaitu perilaku seks bebas. Pemuda remaja menaruh perilaku seks yang demikian sebagai halhal yang memberikan kepuasan dan kesenangan secara pribadi. Akibatnya, perilaku seks bebas, kohabitasi (kumpul kebo) dan pemahaman tentang pernikahan yang salah diterima begitu saja di tengah masyarakat. Hubungan seks tidak lagi didasarkan pada kekudusan melainkan kesepakatan, soal suka dan tidak merugikan orang lain. ${ }^{2}$ Maraknya perilaku seks yang tidak sehat di tengah-tengah kalangan kaum pemuda remaj di Papua telah menjadi sorotan. Menurut data dari National AIDS Commission Republic of Indonesia, 2009 secara umum dengan sangat jelas dan dengan tidak terbantahkan yang terjadi di Tanah Papua adalah bahwa perilaku seksual berisiko (hubungan seks dengan sering berganti-ganti pasangan) bertanggung jawab atas lebih dari $90 \%$ penularan HIV di Papua baik di daerah perkotaan maupun di daerah terpencil (usia 24 tahun). Beberapa penelitian menunjukkan bahwa pola perilaku seksual di Papua sangat relevan dengan penularan HIV bahkan jumlah yang mengalami perilaku seksual dibawah usia 15 tahun secara signifikan lebih tinggi daripada yang ditemukan diantara orang-orang yang berusia lebih tua (25-49 tahun usia). ${ }^{3}$

Perilaku seksual ini lebih dominan terjadi di kalangan wanita dari pada pria. Studi dan diskusi kontemporer menekankan bahwa kurangnya pengetahuan di berbagai bidang oleh kaum wanita, khususnya dalam pengambilan keputusan seksual. ${ }^{4}$ Perkiraan ini menunjukkan bahwa wanita yang berusia 16-29 tahun telah disurvei oleh IBBS, Depkes tahun 2006 sebanyak 20\% -25\% telah melakukan hubungan seks dengan teman

${ }^{1}$ Dayne Trikora Wardani, "Perkembangan dan Seksualitas Remaja", Vol 17, No 3 (2012): 187, diakses 24 November, 2017, https://ejournal.kemsos.go.id/index.php/Sosioinforma/article/view/84

${ }^{2}$ Christ Community an Evangelical Free Church, "Exploring God's Design ForHuman Sexuality“, (February 2015):5, diakses November 25, 2017, https://christcommunitykc.org/wpcontent/uploads/2015/10/Exploring-Gods-Design-For-Human-Sexuality-2015feb.pdf

${ }^{3}$ National AIDS Commission Republic of Indonesia, "Republic of Indonesia Country Report on the Follow up to the Declaration of Commitment On HIV/AIDS (UNGASS) Reporting Period 2008 - 2009", (Jakarta, 2009): 24, diakses November 25, 2017,

http://data.unaids.org/pub/report/2010/indonesia_2010_country_progress_report_en.pdf

${ }^{4}$ Ibid. 
sebaya mereka. Menurut Butt, et.al., di daerah yang mempelajari "seks oportunistik" ini ditandai sebagai berikut: Pertama, Melakukan hubungan seks secara diam-diam dan paling sering terjadi di tempat acara, seperti tarian atau pesta. Kedua, Sering dibutuhkan penggunaan "calo" atau perantara. Ketiga, Terkait dengan pemberian uang atau barang. Keempat, ini ditandai dengan tingginya tingkat mobilitas. Kelima, tampaknya dikaitkan dengan meningkatnya peran uang dalam hubungan seksual.

Dalam penelitian Preventing AIDS in Papua Revised Research Report ditunjukkan pula hasil bahwa sebagian kecil responden mengatakan mereka memiliki kehidupan seks yang sangat aktif. Lebih dari 30\% ( $n=57)$ responden, hampir semuanya adalah laki-laki, mengatakan bahwa mereka memiliki lebih dari 10 pasangan selama perjalanan hidup mereka. Lebih dari seperempat responden tersebut menyatakan bahwa mereka memiliki lebih dari 50 pasangan seksual. Selanjutnya, mayoritas responden pernah berhubungan seks sebelum usia 19 tahun, khususnya semua responden yang diwawancarai di bawah usia 20 tahun telah melakukan hubungan seksual, dengan sejumlah besar responden (29\%) pernah melakukan hubungan seksual pada usia 15 tahun. Pola ini tersebar luas di seluruh provinsi. Berhubungan seks di usia dini nampaknya merupakan fenomena yang relatif umum. ${ }^{5}$ Salah satu faktor yang mempengaruhi seorang muda melakukan hubungan seks adalah pornografi. Pengaruh ini semakin jelas ketika pornografi semakin banyak digunakan untuk pendidikan seks. Tidak cukup itu saja pornografi dijadikan pola dalam aktivitas seksual.

Selain bukti di atas, Pemerhati Perempuan Sri Durjati Boedihardjo mengatakan faktor lain yang menyebabkan maraknya perilaku seks bebas di kalangan pemuda/ remaja Papua adalah karena adat istiadatnya; di mana seorang kepala suku di Papua berhak sesuka hati dan leluasa menyalurkan hasrat biologisnya terhadap siapa saja perempuan di sukunya. Karena jika kepala suku sudah menginginkan perempuan di sukunya, tidak ada lagi yang berani menolaknya. ${ }^{6}$ Beberapa bukti lain yang menunjukkan bahwa perilaku seks bebas ini menjadi persoalan yang harus diperhatikan, yaitu: $35 \%(\mathrm{n}=57)$ responden mengatakan bahwa mereka melakukan hubungan seks dengan lebih dari satu pasangan di tahun sebelumnya, sementara $36 \%$ dari yang selalu pergi ke gereja mengatakan hal yang sama. Lebih dari separuh responden kami mengatakan bahwa mereka telah menikah secara formal di sebuah gereja atau upacara pernikahan tradisional $(55 \%, \mathrm{n}=108)$. Sebanyak 53\% ( $\mathrm{n}=103)$ mengatakan bahwa mereka telah tinggal bersama pasangan tanpa menikah dan beberapa responden pernah mengalami kedua hal tersebut. ${ }^{7}$

Dari semua bukti di atas nampak nilai lain yang berubah adalah karena menurunnya ajaran gereja. Gereja adalah tempat di mana Firman Tuhan diajarkan dengan pemahaman dan cara yang benar oleh gembala kepada jemaatnya. Pemahaman ini juga

${ }^{5}$ Leslie Butt., Gerdha Numbery, Jake Morin, "Preventing AIDS in Papua Revised Research Report", (Desember 2002):15, diakses November 25, 2017, http://papuaweb.org/dlib/tema/hiv-aids/butt2002-prevent.pdf.

${ }^{6}$ Bramantyo, "Seks Bebas di Papua Sangat Mengerikan.” Sindonews, 8 Januari 2014, diakses November 26, 2017, https://daerah.sindonews.com/read/824670/26/seks-bebas-di-papua-sangatmengerikan-1389166898

${ }^{7}$ Ibid., 18 
menyangkut sebuah tindakan nyata dalam membimbing jemaatnya. Tindakan-tindakan nyata dalam membimbing jemaat dapat dilihat dari berbagai kegiatan rohani dalam gereja, misalnya: kegiatan ibadah pemuda/remaja dengan metode diskusi dalam kelompok, pendampingan secara personal bagi jemaat yang mempunyai persoalan. Salah satu bukti dari gagalnya gereja membimbing jemaatnya adalah didapati ada $40 \%$ pemuda/ remaja yang sudah jatuh dalam dosa seks bebas. Dimana $20 \%$ diantaranya masih aktif ke gereja dan masuk dalam pelayanan namun masih tetap tinggal dalam perzinahan dan belum ada penyelesaian secara serius dari Gembala atau Majelis gereja setempat, $14 \%$ diantaranya menghamili dan hamil di luar nikah, 6\% diantaranya tidak aktif ke gereja/ ibadah pemuda karena merasa malu.

Semua data yang didapat dalam tulisan ini tidak bermaksud untuk mengucilkan atau menjatuhkan perilaku seksualitas di Papua, melainkan untuk menarik perhatian kita semua bahwa pemahaman yang salah mengenai hidup kudus terkait dalam perilaku seksual dengan tidak berdasarkan kebenaran Firman Tuhan akan menghancurkan generasi muda di Papua, khususya bagi pemuda/i/ remaja di kalangan GPdI Wilayah Sentani Timur Tengah. Sangat penting untuk mengidentifikasi masalah ini dengan melihat dari sudut pandang Alkitab sebagai tolok ukur tertinggi sehingga para pemimpin gereja, kepala-kepala suku, aktivis dan orang Papua khususnya di kalangan GPdI Wilayah Sentani Timur Selatan yang peduli terhadap kesejahteraan masyarakatnya dapat mengenali pemahaman serta dapat mengajarkan nilai-nilai kebenaran tentang hidup kudus menurut 1 Tesalonika 4: 1-8 terhadap perilaku seksual.

\section{Metodelogi Penelitian}

Penelitian ini akan menggunakan pendekatan kuantitatif (positivis), yang mana penelitian positivis bersandar pada kualifikasi dalam pengumpulan dan analisis data untuk menguji hipotesis yang ditetapkan. ${ }^{8}$ Metode penelitian yang dipergunakan dalam penelitian ini adalah rancangan penelitian kuantitatif dengan metode survei, disebut survei karena penelitian ini menggunakan populasi langsung menjadi sampel yang representatif untuk mengambil kesimpulan dengan menggunakan kuesioner atau angket sebagai pengumpul data ${ }^{9}$ Metode penelitian yang digunakan adalah survei yang bersifat eksplanatori-konfirmatori, yaitu penelitian yang seringkali diidentikkan dengan menggunakan pertanyaan "mengapa" dalam mengembangkan informasi yang ada. ${ }^{10}$ Penelitian ini bersifat eksplanatori karena dalam proses penelitiannya ingin mengkaji/ menggali secara mendalam variable terikat $(\mathrm{Y})$ melalui pengembangan variabel eksogenous dan endogenous.

Penelitian ini dilaksanakan di GPdI Wilayah Sentani Timur Tengah. Dalam penelitian ini, populasi adalah seluruh pemuda/ remaja di GPdI Wilayah Sentani Timur Tengah yang berjumlah 123 orang. Semua populasi menjadi sampel, yang populasi

\footnotetext{
57.

${ }^{8}$ A. Bambang Subagyo, Pengantar Riset Kuantitatif dan Kualitatif (Bandung: Kalam Hidup, 2004),

${ }^{9}$ Fred N. Kerliger and Howard B. Lee, Foundations of Behavioral Research (Forth Worth: Harcout College Publisher, 2000), 559.

${ }^{10}$ Bambang Prasetyo dan Lina Maftahul Jannah, Metode Penelitian Kuantitatif (Jakarta: Raja Grafindo Persada, 2008), 34.
} 
mempunyai peluang yang sama dan tidak terikat untuk dimasukkan ke dalam sampel. Metode dan alat pengumpulan data yang digunakan dalam penelitian ini adalah metode angket. Daftar penelitian yang digunakan untuk penelitian ini menyangkut pengaruh hidup kudus menurut 1 Tesalonika 4:1-8 terhadap perilaku seksual pemuda/remaja Wilayah Sentani Timur Tengah. Metode ini digunakan untuk memperoleh data primer yaitu data yang diperoleh secara langsung dari subyek penelitian melalui pengisian angket. Teknik pengambilan data populasi secara dengan sistem random sampling yaitu pengambilan data dari anggota populasi secara acak, tanpa memperhatikan strata yang ada di dalam populasi. ${ }^{11}$

Instrumen penelitian ini menggunakan validitas isi (content validation) dan validitas konstruksi (construct validation). Pendekatan validitas konstruksi ini dilakukan dengan dua tahap yaitu melakukan analisis data dengan pendekatan yang berbeda yaitu Faktor Analisis dengan metode Principel Component Axis yang beriterasi Varimax. Selain itu, untuk memahami konsep hidup kudus dalam 1 Tesalonika 4:1-8 menggunakan pendekatan eksegesis.

\section{Eksegesis Surat 1 Tesalonika 4:1-8}

Perintah Tuhan (Ayat 1, 2)

Awal dari perikop ini ditandai dengan ungkapan $\Lambda$ oเтòv oûv, diterjemahkan: akhirnya. Kata-kata ini menunjukkan bahwa Paulus tidak akan membahas masalah yang sangat kontroversial, tetapi Paulus meminta orang Tesalonika untuk hidup sesuai dengan perintah yang ia berikan kepada mereka. ${ }^{12}$ Dalam tiga perikop pertama Paulus memuji orang-orang Tesalonika atas kesetiaan mereka dan mengidentifikasi diri dengan penderitaan mereka. Paulus mengingatkan mereka tentang kepedulian dan kebanggaan sehingga hal tersebut Paulus jadikan contoh yang baik dari kasih dan pelayanan Kristen. Namun dalam perikop ini Paulus akan mendesak mereka dalam beberapa hal yang sangat praktis. Hal ini berkaitan dengan kehidupan orang Kristen yang harus berproses dan berkembang.

Kata-kata mendesak (bertanya) dan menasihati (mendorong) ada dalam active present tense, yaitu, "kami terus mendesak dan menasihati kamu untuk semakin dan semakin unggul, jangan tetap statis dan tumbuh 'lama' dalam satu perjalanan Kristen". Kata menasihati juga mensyaratkan gagasan "datang berdampingan" dalam arti mengidentifikasi secara pribadi dengan orang-orang percaya. Dalam hal ini Paulus tidak menegur tetapi lebih kepada menunjukkan kasih dan perhatian yang Paulus miliki bagi kesejahteraan orang percaya. ${ }^{13}$ Kata yang diterjemahkan perintah adalah parangelia yang berarti instruksi; Paulus menggunakan kata yang sama dalam 1 Timotius 1: 5,18 untuk merujuk pada keseluruhan pengajaran Kristen praktis atau practical teaching of

\footnotetext{
${ }^{11}$ Suharsimi Arikunto, Prosedur Penelitian Suatu Pendekatan Praktik (Jakarta: Rineka Cipta, 1998), 58

${ }^{12}$ Eduard Verhoef, "I Thessalonians 4:1-8: The Thessalonians should live a holy life" (Maartensdijk, The Netherlands:2007):348

${ }^{13}$ Klaus G. Schiessel, "1 THESSALONIANS 4:1-12 The Goal of a Christian Life: The 2nd Coming of Christ is a Purifying Hope", (Desember, 2008):1, diakses pada 5 November 2019, http://storage.cloversites.com/journeythruthebiblesundayschoolclass/documents/1Thess04-1.pdf
} 
Christianity. Dalam dunia militer Romawi, ini adalah kata yang digunakan untuk menggambarkan perintah yang diturunkan dalam rantai komando. Hal ini menggambarkan orang Percaya adalah pelayan di rumah Tuhan atau dengan kata lain orang Percaya sama dengan prajurit Tuhan yang harus melakukan perintah. Seperti tulisan Paulus; "Seorang prajurit yang sedang tugas, tidak akan menyibukkan dirinya dengan urusan-urusannya sendiri, sebab ia ingin menyenangkan hati panglimanya." (2 Tim. 2: 4 BIS). ${ }^{14}$

Dari ayat satu dan dua ini dapat dilihat dengan jelas bahwa Paulus berbicara dengan otoritas Yesus Kristus sendiri. Pesan dari perintah yang dibawa oleh Paulus ini bertujuan untuk menyenangkan Tuhan. Harapan Paulus adalah agar saudara-saudaranya di Tesalonika dapat mencintai Kristus dengan membentuk pola hidup serta perilakunya sesuai dengan apa yang menyenangkan Allah.

\section{Orang Percaya Berkarakter Kudus: Kemurnian Seksual (ayat 3-8)}

1 Tesalonika 4:3-8 memuat satu dalam kategori "cara hidup" etika dasar dan gaya hidup orang Kristen. Dalam pelajaran ini akan dilihat ajaran Paulus tentang: Perilaku seksual (4: 3-8), di antaranya:

Pertama, menjauhkan diri dari percabulan (ay. 3). Paulus memerintahkan orangorang percaya untuk "menjauhkan diri dari" (NRSV, KJV) amoralitas seksual. Ungkapan ini mirip dengan Kis 15:20, 29, dalam surat dari Dewan Yerusalem bahwa Silas telah dibebankan untuk dibawa ke gereja-gereja non-Yahudi. "Seksual imoralitas" (NIV), "percabulan" (NRSV, KJV) adalah porneia, "hubungan seksual yang melanggar hukum, pelacuran, ketidaksucian, percabulan." dapat menunjukkan segala bentuk hubungan seksual terlarang. Homoseksualitas juga akan dimasukkan dalam istilah ini. Sementara istilah, "kesucian" dalam bahasa Inggris adalah, "menjaukan diri dari hubungan seksual yang melanggar hukum." Namun, pengertian dasarnya bukan berarti menahan diri dari hubungan seksual dalam pernikahan. "Percabulan," (terjemahan KJV dari porneia) berarti dalam bahasa Inggris, "hubungan seksual konsensual antara dua orang yang tidak menikah satu sama lain." Biasanya mengacu pada orang yang belum menikah. Sedangkan perzinahan mengacu pada urusan di luar nikah dari individu yang menikah.

Paulus tidak mengutuk seks. Tetapi Paulus memerintahkan bahwa hubungan seksual dilakukan secara ketat dalam pernikahan, seperti kehendak Tuhan yang dinyatakan. Kata benda yang diterjemahkan sebagai "dikuduskan" adalah hagiasmos, "pengabdian pribadi untuk kepentingan Tuhan, kekudusan, pengudusan, pengudusan." Kata ini digunakan dalam Perjanjian Baru dalam pengertian moral untuk suatu proses atau, lebih sering (seperti dalam 4: 3), akibatnya, yaitu keadaan yang disucikan. Proses ini juga dikenal sebagai "pengudusan." Konsep kekudusan dimulai dalam Perjanjian Lama. Sejak awal, Allah telah memerintahkan, "Jadilah kudus, karena Aku kudus" (Im. 11: 45b). Sehingga Kekudusan bukanlah suatu pilihan melainkan perintah.

\footnotetext{
${ }^{14}$ Calvarycsd, "The Walk That Pleases God 1 Thessalonians 4:1-8", (1 Desember 2012): 2, diakses pada 5 November 2019, http://www.calvarycsd.org/wp-content/uploads/2012/12/1-Thessalonians-4-18.pdf
} 
Kedua, menghormati tubuh istrinya (ay. 4). Dalam ayat ini dapat diartikan menjadi dua terjemahan. Berikut adalah dua terjemahan yang representatif:

"Kamu masing-masing harus tahu bagaimana memiliki istri dalam pengudusan dan penghormatan" (KJV, NASB).

"Kamu masing-masing harus belajar mengendalikan tubuhnya sendiri dengan cara yang suci dan terhormat" (NIV, NRSV).

Memiliki vessel-nya/kapalnya/wadah berarti memiliki istri atau pasangannya. Kata kerja ktaomai berarti "untuk memiliki, mendapatkan bagi diri sendiri, memperoleh, mendapatkan." Dalam terjemahan Septuaginta penggunaan kata ini berarti untuk mendapatkan seorang istri dalam Rut 4:10, dan dalam buku Apokrifa Sirakh 36:29. Kata benda yang diterjemahkan "bejana" (KJV), "tubuh" (NIV, NRSV) adalah skeuos, pertama, "benda, objek," lalu, "wadah dalam bentuk apa pun, toples," dan di sini, seorang manusia yang menggunakan fungsi atau alat sebagai vessel/wadah.

Paulus menekankan kekudusan dan kehormatan disini bukan dalam nafsu birahi seperti orang yang tidak mengenal Tuhan. "Passionate lust" (NIV), "lustful passion" (NRSV) atau "the lup of concupiscence" (KJV) terdiri dari dua kata dalam bahasa Yunani: pathos yaitu pengalaman hasrat kuat dan epithymia, yaitu keinginan untuk sesuatu yang dilarang atau semata-mata tak terkendali, keinginan, nafsu. Dalam ayat ini hasrat seksual tentu saja, hubungan seksual melibatkan gairah fisik. Tuhan menciptakan manusia dengan cara ini. Tetapi hasrat itu perlu dikendalikan dan disalurkan secara eksklusif terhadap mereka yang sudah memiliki pasangan (suami/istri).

Ketiga, mengontrol hasrat seksual (ay. 5). Mengontrol tubuh sendiri dan orang lain khususnya, organ seksual. Paulus cukup jelas menerangkan bahwa manusia diperintahkan untuk mengendalikan hasrat seksualnya, agar kehidupan seksual itu dapat dilakukan dalam kekudusan (hagiasmos) dan penuh penghormatan. (4: 4b, NRSV). Paulus tidak mengatakan bahwa hasrat seksual itu jahat, hanya saja ada cara yang salah dan benar untuk mengekspresikannya. Tuhan telah membuat hubungan seksual untuk dinikmati dan mengarah pada prokreasi umat manusia. Tetapi segala sesuatu yang menyimpang atau dikeluarkan dari konteks yang Allah maksudkan adalah dosa. Sebagai suami dan istri, penting untuk memiliki gairah dalam pernikahan.

Keempat, jangan menyalahkan atau mengambil keuntungan dari saudara kita (ay. 6). Paulus merujuk pada kecurangan seksual atau perzinaan di dalam komunitas Kristen di sini, karena Paulus menggunakan istilah "saudara." Ini juga melibatkan kecurangan, melakukan sesuatu di belakang seseorang. Jika seorang pria melakukan hubungan seks dengan seorang wanita yang belum menikah di komunitas Kristen, dalam arti wanita tersebut akan menipu calon suaminya. Di sini Paulus mengantisipasi dan memahami praktik incest yang umum dilakukan orang-orang kafir; praktik seksual dengan anggota keluarga tidak bermoral dan Tuhan tidak akan membiarkan kesalahan itu dilakukan, bahkan di antara anggota keluarga.

Dalam bagian lain di ayat 6 dikatakan pula bahwa Allah akan menghukum para pelanggar sila ini. Kata-kata ini menekankan pentingnya masalah ini. Paulus mendesak orang Tesalonika untuk mendengarkan dengan seksama dan untuk mematuhi hukuman 
ini. Jika mereka taat dan hidup suci mereka akan mengambil bagian di masa depan bersama Tuhan. Akhirnya Paulus mengingatkan mereka bahwa Paulus sudah berbicara tentang semua hal ini sebelumnya dan Paulus mengkonfirmasi kembali apa yang sudah mereka ketahui.

Kelima, tubuh ini adalah milik Allah (ay. 7). Seks harus dilakukan dengan penuh rasa hormat. Tubuh manusia adalah sepenuhnya milik Tuhan. Hal Ini membutuhkan kewaspadaan dan disiplin diri yang kuat, terutama bagi orang-orang baru dari dunia yang terbiasa melakukan amoralitas seksual. Ada istilah lain yang merujuk pada keadaan "suci" di sini. Yang dimaksud Paulus adalah Allah telah menyelamatkan umatNya oleh Yesus Kristus. Disini juga ditegaskan bahwa jemaat di Tesalonika harus memiliki kontrol atas tubuh mereka dengan cara yang kudus dan terhormat dan tidak membiarkan diri mereka dipimpin oleh hasrat yang tamak.

Keenam, jangan menolak perintah Allah. Dalam ayat delapan pada perikop ini ditutup dengan peringatan umum bahwa orang-orang yang menolak perintah-perintah ini menolak Allah akan menanggung akibatnya. Penolakan terhadap standar moral yang dijelaskan di sini merupakan hal yang sangat serius. Setiap orang yang mengabaikan pengajaran Alkitab tentang kemurnian seksual ini tidak hanya menolak standar buatan manusia tetapi juga Allah yang telah memberi Roh Kudus-Nya. Paulus berbicara pesan ini karena ini adalah perintah Allah, sehingga ketika umat Allah mengabaikan pengajaran Paulus sama artinya dengan pemberontakan terhadap Allah sendiri.

\section{Hidup Kudus menurut Kitab 1 Tesalonika 4: 1-8}

Berdasarkan 1 Tesalonika 4: 1-8, Hidup Kudus memiliki beberapa pengertian, yaitu: Hidup kudus adalah hidup yang berkenan kepada Allah (1 Tes. 4:1); Hidup kudus dilakukan secara terus menerus (1 Tes.4: 1); Hidup kudus adalah kunci berkat rohani (1 Tes.4:1); Hidup kudus adalah pesan Tuhan melalui Paulus bagi orang percaya (1 Tes.4: 2); Hidup kudus adalah tidak melakukan semua kenajisan atau segala perilaku yang memalukan baik dalam tindakan, ucapan dan pikiran. (1 Tes.4: 3); Hidup kudus adalah tanda seseorang menjadi milik Allah (1 Tes.4:3); Hidup kudus adalah hidup yang menjauhi percabulan (perilaku seksual menyimpang) yaitu: (1) hubungan seksual terlarang, (2) perzinahan, (3) percabulan, (4) homoseksualitas, (5) lesbianisme, (6) hubungan seksual dengan binatang, (7) hubungan seksual dengan kerabat dekat, (8) hubungan seksual dengan pria atau wanita yang bercerai (1 Tes.4: 3); Hidup kudus adalah melakukan hubungan seks dalam ikatan pernikahan yang sudah disahkan secara hukum dan gereja. (1 Tes.4: 4); Hidup kudus adalah melakukan hubungan seks secara benar, penuh rasa hormat dan bukan atas dorongan hawa nafsu. (1 Tes.4: 5); Hidup kudus adalah tidak melakukan perselingkuhan/ tidak memanfaatkan orang lain. (1 Tes.4:6); Hidup kudus adalah panggilan setiap orang percaya untuk melakukan apa yang kudus (1 Tes.4:7); Hidup kudus adalah tanda bahwa hidup kita bersatu dengan Kristus. (1 Tes.4:7); Hidup kudus adalah sikap penerimaan manusia akan Allah (1 Tes.4:8). 


\section{Hasil dan Pembahasan}

\section{Uji Normalitas}

Uji normalitas digunakan untuk mengetahui apakah populasi data berdistribusi normal atau tidak. Uji normalitas yang digunakan dalam penelitian ini adalah uji One sample Kolmogrov-smirnov dengan menggunakan taraf signifikasi 0,05. Data dinyatakan berdistribusi normal jika signifikasi lebih besar dari 5\% atau 0,05. Hasil dari tabel ini menunjukkan nilai probabilitas 0,32 > 0,05 maka distribusi data terbukti normal.

\section{Tabel 1: Uji Normalitas}

\begin{tabular}{|c|c|c|}
\hline \multicolumn{3}{|c|}{ One-Sample Kolmogorov-Smirnov Test } \\
\hline & & Unstandardized Residual \\
\hline \multicolumn{2}{|l|}{$\mathrm{N}$} & 123 \\
\hline \multirow[t]{2}{*}{ Normal Parameters ${ }^{\mathrm{a}, \mathrm{b}}$} & Mean & .0000000 \\
\hline & Std. Deviation & 5.66377478 \\
\hline \multirow[t]{3}{*}{ Most Extreme Differences } & Absolute & .084 \\
\hline & Positive & .051 \\
\hline & Negative & -.084 \\
\hline \multicolumn{2}{|l|}{ Test Statistic } & .084 \\
\hline \multicolumn{2}{|l|}{ Asymp. Sig. (2-tailed) } & $.032^{\mathrm{c}}$ \\
\hline \multicolumn{3}{|l|}{ a. Test distribution is Normal. } \\
\hline \multicolumn{3}{|l|}{ b. Calculated from data. } \\
\hline \multicolumn{3}{|c|}{ c. Lilliefors Significance Correction. } \\
\hline
\end{tabular}

\section{Regresi Linier Sederhana}

Analisis Regresi Linier Sederhana adalah hubungan secara linier antara satu variabel independen $(\mathrm{X})$ dan variabel dependen $(\mathrm{Y})$. Analisis ini untuk mengetahui ada tidaknya pengaruh antara variabel.

Tabel 2: Metode Enter

\begin{tabular}{|c|c|c|c|}
\hline \multicolumn{4}{|c|}{ Variables Entered/Removed ${ }^{\mathrm{a}}$} \\
\hline Model & Variables Entered & Variables Removed & Method \\
\hline 1 & $\begin{array}{l}\text { Pemahaman Hidup } \\
\text { Kudus Menurut } 1 \\
\text { Tes } 4: 1-8^{\text {b }}\end{array}$ & . & Enter \\
\hline \multicolumn{4}{|c|}{$\begin{array}{l}\text { a. Dependent Variable: Perilaku Seksual Pemuda/Remaja GPdI Sentani } \\
\text { Timur Tengah }\end{array}$} \\
\hline \multicolumn{4}{|c|}{ b. All requested variables entered. } \\
\hline
\end{tabular}

Tabel di atas menjelaskan tentang variabel yang dimasukkan serta metode yang digunakan. Dalam hal ini variabel yang dimasukkan adalah variable X di mana pemahaman hidup kudus menurut 1 Tesalonika 4:1-8 sebagai variable independent dan perilaku seksual pemuda/remaja GPdI Sentani Timur Tengah sebagai variabel dependent dan metode yang digunakan adalah metode Enter.

Tabel 3: Uji Korelasi

\begin{tabular}{|c|c|c|c|c|}
\hline Model & R & R Square & Adjusted R Square & $\begin{array}{c}\text { Std. Error of the } \\
\text { Estimate }\end{array}$ \\
\hline 1 & $.926^{\mathrm{a}}$ & .857 & .856 & 5.68713 \\
\hline
\end{tabular}

Predictors: (Constant), Pemahaman Hidup Kudus Menurut 1 Tes 4:1-8 
Tabel di atas menjelaskan besarnya nilai korelasi/ hubungan (R) yaitu sebesar 0,926. Dari output tersebut diperoleh koefisien determinasi ( $\mathrm{R}$ square) sebesar 0,857 yang mengandung pengertian bahwa pengaruh variable $X$ (Pemahaman Hidup Kudus menurut 1 Tesalonika 4:1-8) terhadap variabel Y (Perilaku Seksual Pemuda/Remaja GPdI Sentani Timur Tengah) adalah sebesar 85,7\%.

Tabel 4: Uji F

\begin{tabular}{|l|l|l|l|l|l|l|}
\hline \multicolumn{2}{|l|}{ ANOVAa } \\
\hline \multicolumn{2}{|l|}{ Model } & Sum of Squares & df & Mean Square & F & Sig. \\
\hline \multirow{3}{*}{1} & Regression & 23429.434 & 1 & 23429.434 & 724.395 & $.000 \mathrm{~b}$ \\
\cline { 2 - 8 } & Residual & 3913.558 & 121 & 32.343 & & \\
\cline { 2 - 8 } & Total & 27342.992 & 122 & & & \\
\hline
\end{tabular}

Dari output di atas diketahui bahwa nilai $\mathrm{F}$ hitung $=724,395$ dengan tingkat signifikansi sebesar $0,000<0,05$ maka model regresi dapat dipakai untuk memprediksi variabel Perilaku Seksual Pemuda/Remaja GPdI Sentani Timur Tengah. Dengan kata lain, adanya pengaruh variabel Pemahaman Hidup Kudus menurut 1 Tesalonika 4:1-8 (X) terhadap variabel Perilaku Seksual Pemuda/Remaja GpdI Sentani Timur Tengah (Y).

Tabel 5: Uji Hipotesis

\begin{tabular}{|c|c|c|c|c|c|c|}
\hline \multicolumn{7}{|c|}{ Coefficientsa } \\
\hline \multirow{2}{*}{\multicolumn{2}{|c|}{ Model }} & \multicolumn{2}{|c|}{$\begin{array}{l}\text { Unstandardized } \\
\text { Coefficients }\end{array}$} & $\begin{array}{l}\text { Standardized } \\
\text { Coefficients }\end{array}$ & \multirow[t]{2}{*}{$\mathrm{t}$} & \multirow[t]{2}{*}{ Sig. } \\
\hline & & $\mathrm{B}$ & Std. Error & Beta & & \\
\hline \multirow[t]{2}{*}{1} & (Constant) & -47.727 & 6.241 & & -7.647 & .000 \\
\hline & $\begin{array}{l}\text { Pemahaman } \\
\text { Hidup Kudus } \\
\text { Menurut } 1 \text { Tes } \\
4: 1-8\end{array}$ & .864 & .032 & .926 & 26.915 & .000 \\
\hline
\end{tabular}

a. Dependent Variable: Perilaku Seksual Pemuda/Remaja GPdI Sentani Timur Tengah

Diketahui nilai Constant (a) sebesar -47,727, sedangkan nilai Pemahaman Kudus menurut 1 Tesalonika 4:1-8 (b/koefisien regresi) sebesar 0,864 sehingga persamaan regresinya dapat diterjemahkan menjadi koefisien regresi $\mathrm{X}$ sebesar 0,864 yang menyatakan bahwa setiap pertumbuhan $1 \%$ nilai pemahaman hidup kudus maka tingkat dari perilaku seksual Pemuda/Remaja GPdI Sentani Timur Tengah akan bertambah sebesar 0,864. Koefisien tersebut bernilai positif sehingga dapat dikatakan bahwa arah pengaruh variabel $\mathrm{X}$ terhadap Y adalah positif.

Berdasarkan nilai signifikansi dari tabel koefisien diperoleh nilai signifikansi sebesar $0,000<0,05$ sehingga dapat disimpulkan bahwa variabel Pemahaman hidup kudus menurut 1 Tesalonika 4:1-8 (X) berpengaruh terhadap variabel Perilaku seksual Pemuda/Remaja GPdI Sentani Timur Tengah (Y). Berdasarkan nilai t: diketahui nilai $\mathrm{t}_{\text {hitung }}$ sebesar 26,915 > $\mathrm{t}_{\text {tabel, }}$, sehingga dapat disimpulkan bahwa variabel pemahaman hidup kudus menurut 1 Tesalonika 4:1-8 (X) berpengaruh terhadap variabel perilaku seksual Pemuda/Remaja GPdI Sentani Timur Tengah (Y). 
Tabel 6: Koefisien Determinan

\begin{tabular}{|l|l|l|l|l|}
\hline Model & R & R Square & Adjusted R Square & $\begin{array}{l}\text { Std. Error of the } \\
\text { Estimate }\end{array}$ \\
\hline 1 & $.926^{\mathrm{a}}$ & .857 & .856 & 5.68713 \\
\hline
\end{tabular}

a. Predictors: (Constant), Pemahaman Hidup Kudus Menurut 1 Tes 4:1-8

Setelah $\mathrm{r}_{\text {hitung }}$ diketahui sebesar 0,421 maka selanjutnya untuk mengetahui seberapa besar pengaruh variabel $\mathrm{X}$ terhadap variabel $\mathrm{Y}$ dengan menggunakan koefisien determinan $r^{2}$. Dari hasil perhitungan di atas maka dapat disimpulkan bahwa ada pengaruh variabel X terhadap Y sebesar $86 \%$ dan selebihnya sebesar $14 \%$ dipengaruhi oleh faktor lain.

\section{Deskripsi Data Kecenderungan Dimensi dalam Penelitian}

Berdasarkan data yang diolah dengan bantuan SPSS versi 19.0 for windows, untuk 8 dimensi pada variabel $\mathrm{X}$ dalam terhadap variabel $\mathrm{Y}$ dapat diketahui menggunakan rumus Sumbangan Efektif (SE) dan Sumbangan Relatif (SR) sebagai berikut:

Tabel 7: Data Persyaratan SE dan SR

\begin{tabular}{|c|c|c|c|}
\hline Dimensi & Koefisien Regresi (Beta) & Koesfisien Korelasi & R Square \\
\hline D1 & 0,245 & 0,759 & \\
\hline D2 & 0,114 & 0,628 & \multirow{2}{*}{88,4} \\
\hline D3 & 0,213 & 0,607 & \\
\cline { 1 - 3 } D4 & 0,103 & 0,634 & \\
\hline D5 & 0,031 & 0,398 & \\
\hline D6 & 0,248 & 0,747 & \\
\hline D7 & 0,065 & 0,544 & 0,738 \\
\hline D8 & 0,270 & 0, & \\
\hline
\end{tabular}

Hasil Persentase SE

\begin{tabular}{|l|c|}
\hline SE & NILAI \\
\hline D1 & $18,6 \%$ \\
\hline D2 & $7,1 \%$ \\
\hline D3 & $13,0 \%$ \\
\hline D4 & $6,5 \%$ \\
\hline D5 & $1,2 \%$ \\
\hline D6 & $18,5 \%$ \\
\hline D7 & $3,5 \%$ \\
\hline D8 & $20,0 \%$ \\
\hline R SQUARE & 88,4 \\
\hline
\end{tabular}

Hasil Persentase SR

\begin{tabular}{|l|c|}
\hline SR & NILAI \\
\hline D1 & 21,0 \\
\hline D2 & 8,0 \\
\hline D3 & 14,7 \\
\hline D4 & 7,35 \\
\hline D5 & 1,35 \\
\hline D6 & 21,0 \\
\hline D7 & 4,0 \\
\hline D8 & 22,6 \\
\hline R SQUARE & 100,00 \\
\hline
\end{tabular}

Dari data hasil tabel di atas maka dapat dilihat dimensi delapan yaitu penerimaan akan kehadiran Allah adalah dimensi yang memberikan sumbangan efektif dengan presentase paling tinggi yaitu sebesar 20\% dan sumbangan relative sebesar 22,6\% dengan kata lain dimensi delapan merupakan dimensi yang lebih dominan dibandingkan dimensi lainnya. 


\section{Pembahasan Penelitian}

\section{Interpretasi Hasil Penelitian}

Berdasarkan hasil analisis yang telah diuraikan di atas diperoleh hasil bahwa variabel (X) pemahaman hidup kudus menurut 1 Tesalonika 4:1-8 berpengaruh signifikan terhadap variabel (Y) perilaku seksual Pemuda/Remaja GPdI Sentani Timur Tengah. Hal tersebut ditunjukkan dari hasil analisis kolerasi product moment sebesar 0,926 dibandingkan dengan $r_{\text {tabel }}$ tingkat signifikan $5 \% \mathrm{~N}=123$ sebesar 0,175 . Jadi $\mathrm{r}_{\text {hitung }}$ lebih besar dari $\mathrm{r}_{\text {tabel}}$, maka dapat ditarik kesimpulan bahwa hipotesis nol (Ho) ditolak dan (Ha) diterima. Dengan koefisien determinasi sebesar 85,7\% dibulatkan (86\%) atau $86 \%$ maka berpengaruh positif. Hal ini mengartikan jika semakin tinggi pemahaman hidup kudus menurut 1 Tesalonika 4:1-8 maka semakin tinggi pula perilaku seksual yang positif pada pemuda/remaja GPdI Sentani Timur Tengah. Sedangkan 14\% merupakan faktor lain yang mempengaruhi variabel $Y$ dan yang tidak diteliti oleh peneliti namun peneliti sudah memberikan gambaran secara sederhana dalam bentuk diagram pada penjelasan sebelumnya di atas.

Dari hasil analisi uji t diketahui bahwa ada pengaruh yang signifikan variabel (X) pemahaman hidup kudus menurut 1 Tesalonika 4:1-8 dan variabel (Y) perilaku seksual pemuda/remaja GPdI Sentani Timur Tengah. Hal ini dibuktikan dengan hasil perhitungan uji $\mathrm{t}$ sebesar 26.915, sedangkan pada $t_{\text {tabel }}$ adalah 1.979 pada taraf signifikansi $5 \%$ yang berarti bahwa Ha diterima. Ha yaitu : Ada pengaruh pemahaman hidup kudus menurut 1 Tesalonika 4:1-8 terhadap perilaku seksual Pemuda/Remaja GPdI di Sentani Timur Tengah, dan menolak Ho, yaitu tidak ada pengaruh pemahaman hidup kudus menurut 1 Tesalonika 4:1-8 terhadap perilaku seksual Pemuda/Remaja GPdI di Sentani Timur Tengah.

Diketahui pula nilai dari Constant (a) sebesar -47,727, sedangkan nilai pemahaman kudus menurut 1 Tesalonika 4:1-8 (b/ koefisien regresi) sebesar 0,864 sehingga persamaan regresinya dapat diterjemahkan menjadi koefisien regresi $\mathrm{X}$ sebesar 0,864 yang menyatakan bahwa setiap pertumbuhan $1 \%$ nilai pemahaman hidup kudus maka tingkat dari perilaku seksual Pemuda/Remaja GPdI Sentani Timur Tengah akan bertambah sebesar 0,864 . Koefisien tersebut bernilai positif sehingga dapat dikatakan bahwa arah pengaruh variabel $\mathrm{X}$ terhadap $\mathrm{Y}$ adalah positif.

Dengan demikian dapat ditarik sebuah kesimpulan bahwa pemahaman hidup kudus menurut 1 Tesalonika 4:1-8 memiliki pengaruh terhadap perilaku seksual pemuda/remaja GPdI di Sentani Timur Tengah, di mana jika pemuda/remaja dapat memahami makna hidup kudus menurut 1 Tesalonika 4:1-8 secara benar maka perilaku seksualnya pun akan dilakukan secara benar sesuai dengan yang Firman Tuhan ajarkan dan sebaliknya jika pemuda/remaja tidak dapat memahami makna hidup kudus menurut 1 Tesalonika 4:1-8 secara benar maka perilaku seksualnya pun akan dilakukan secara tidak benar sesuai dengan yang Firman Tuhan.

\section{Interpretasi Hasil Sumbangan Efektif dan Sumbangan Relatif}

Dengan melihat tabel hasil uji SE dan SR dengan menggunakan SPSS 20.0 for Windows diketahui bahwa dimensi yang paling dominan dalam pemahaman hidup 
kudus menurut 1 Tesalonika 4:1-8 (X) terhadap perilaku seksual remuda/remaja di wilayah GPdI Sentani Timur Tengah adalah dimensi delapan mengenai "penerimaan akan kehadiran Allah" dimana dimensi ini telah memberikan sumbangan efektif dengan presentase paling tinggi yaitu sebesar 20\% dan sumbangan relatif sebesar 22,6\%. Dengan kata lain dimensi yang ke delapan merupakan dimensi yang lebih berpengaruh dibandingkan dimensi lainnya karena memiliki persentase paling tinggi.

\section{Interpretasi hasil Moderator Variabel}

Berdasarkan hasil persentase identitas responden dengan menggunakan aplikasi google form maka dapat diketahui bahwa latar belakang responden yang paling mempengaruhi hasil kuisioner adalah pada jenis kelamin perempuan yaitu sebesar 63,3\%. Dari hasil data yang diperoleh tersebut menunjukkan bahwa lebih banyak kaum perempuan yang tidak memahami dengan benar makna hidup kudus menurut 1 Tes.4:1-8 sehingga perilaku seksualnya pun dilakukan secara negatif karena tidak sesuai dengan pemahaman Firman Tuhan yang benar.

\section{Kesimpulan}

Hasil uji regresi linear sederhana menunjukkan $Y=-47,727+0,864 X$. Hal ini menunjukkan bahwa terdapat pengaruh positif. Dilanjutkan dengan hasil uji hipotesis, pemahaman hidup kudus menurut 1 Tesalonika 4:1-8 (X) berpengaruh positif terhadap perilaku seksual pemuda/remaja GPdI di Sentani Timur Tengah (Y) yang ditunjukkan dengan nilai t hitung (26.915) > t tabel (1.979), yang berarti Ho ditolak dan Ha diterima. Dimensi yang paling dominan dalam pemahaman hidup kudus menurut 1 Tesalonika 4:1-8 (X) terhadap perilaku seksual pemuda remaja di wilayah GPdI Sentani Timur Tengah adalah mengenai "penerimaan akan kehadiran Allah", di mana dimensi ini telah memberikan sumbangan efektif dengan presentase paling tinggi yaitu sebesar $20 \%$ dan sumbangan relatif sebesar $22,6 \%$.

\section{Referensi}

"Hidup Kudus", Alkitab Sabda, diakses 28 Oktober 2019, https://alkitab.sabda.org/commentary.php?passage $=1+$ Tesalonika+4\%3A18\#Wycliffe_2

Apple, Paul, "Until He Comes Commentary On Book Of 1 Thessalonians" (September 2009): 129-130, diakses September 28, 2017, bibleoutlines.com/library/pdf/1thessalonians.pdf

Arikunto, Suharsimi, Prosedur Penelitian Suatu Pendekatan Praktik, Jakarta: Rineka Cipta, 1998

Bradley, et al., The Impact of Spirituality and Religiosity on Unprotected Sex for Adult Women, American journal of health behavior, 2016

Bramantyo, "Seks Bebas di Papua Sangat Mengerikan." Sindonews, 8 Januari 2014, diakses November 26, 2017, https://daerah.sindonews.com/read/824670/26/seksbebas-di-papua-sangat-mengerikan-1389166898

Brook ,Kelly, Education Of Sexuality For Teenager, North Carolina : Charm press, 2001

Butt, Leslie, Gerdha Numbery, Jake Morin, "Preventing AIDS in Papua Revised Research Report", (Desember 2002):15, diakses November 25, 2017, http://papuaweb.org/dlib/tema/hiv-aids/butt-2002-prevent.pdf. 
Calvarycsd,"The Walk That Pleases God 1 Thessalonians 4:1-8", (1 Desember 2012): 2, diakses pada 5 November 2019, http://www.calvarycsd.org/wpcontent/uploads/2012/12/1-Thessalonians-4-1-8.pdf

Calvin, John, "Commentary On Philippians, Colossians, andThessalonians", (Desember 1999): $177, \quad$ diakses $\quad$ Oktober, 2019, http://www.ccel.org/ccel/calvin/calcom42.html

Chaplin, J.P., Kamus Lengkap Psikologi,Jakarta: Raja Grafindo Persada, 2002.

Christ Community an Evangelical Free Church, "Exploring God's Design ForHuman Sexuality“, (February 2015):5, diakses November 25, 2017, https://christcommunitykc.org/wp-content/uploads/2015/10/Exploring-GodsDesign-For-Human-Sexuality-2015feb.pdf

Departemen Literatur Gereja Yesus Sejati, "Pemahaman Alkitab TESALONIKA TIMOTIUS - TITUS” (2017), diakses 27 Oktober 2017, http://members.tjc.org/sites/en/.pdf

Fachri, A., Perkawinan Sek dan Hukum, Pekalongan: Bahagia. 1986

Farida,"Pergaulan Bebas dan hamil Pranikah", Volume XVI, No. 01, Januari - Juni 2009

Festinger, Comparative Social Phsychology Theorie, Jakarta: Gramedia, 2001

Hadiwirawan, Olivia, "Sikap Terhadap Perilaku Seksual Pranikah Ditinjau Dari Religiusitas dan Konformitas Pada Remaja Di Jakarta", Universitas Kristen Krida Wacana-Jakarta, Fakultas Psikologi, 2015

Henry, Matthew, Commentary Bibleworks, CD-Rom. Versi 7

Joones, Deena, Talking About Sex, Orlando press, 1999

Kerlinger, Fred N and Howard B. Lee, Foundations of Behavioral Research, Forth Worth: Harcout College Publisher, 2000

Khusnul, Analisis Hukum Islam Terhadap Pandangan Hakim Pengadilan Agama Nganjuk Tentang Hiperseksual Sebagai Alasan Untuk Mengajukan Pperceraian, Universitas Islam Negeri Sunan Ampel, Fakultas Syariah dan Hukum, 2005

Maulana, "Gambaran Perilaku Seksual Pra Nikah Pada Anak Jalanan Di Kecamatan Semarang Utara", Universitas Muhammadiyah Semarang, 2013

Miranti, Nadya, Kondisi Psikologis Pada Biseksual: Studi Kasus pada Mahasiswa Biseksual di Yogyakarta, Universitas Islam Negeri Sunan Kalijaga Yogyakarta, 2013

National AIDS Commission Republic of Indonesia, "Republic of Indonesia Country Report on the Follow up to the Declaration of Commitment On HIV/AIDS (UNGASS) Reporting Period 2008 - 2009”, (Jakarta, 2009): 24, diakses November 25 , http://data.unaids.org/pub/report/2010/indonesia_2010_country_progress_report_ en.pdf

Nevid, Rathus., Greene. Psikologi Abnormal, Edisi Kelima Jilid 2, Jakarta: Erlangga,2003

Prasetyo, Bambang dan Lina Maftahul Jannah, Metode Penelitian Kuantitatif, Jakarta: Raja Grafindo Persada, 2008

Purnawan, I, "Faktor-Faktor Yang Mempengaruhi Perilaku Seksual Pada Anak Jalanan di Stasiun Kereta Api Lempuyangan Jogjakarta", Program Studi Ilmu Keperawatan, Fakultas Kedokteran UGM, 2004

Sari, Suci Nofita, "Perilaku Seksual dan Faktor yang Berhubungan pada Mahasiswa S1 Reguler Fakultas X Universitas Indonesia Tahun 2012”, Universitas Indonesia, Fakultas Kesehatan Masyarakat Departemen Epidemiologi, 2012

Sarwono, S.W., Psikologi Remaja, Jakarta: PT. Raja Grafindo Persada, 2006 
Schiessel, Klaus G., "1 THESSALONIANS 4:1-12 The Goal of a Christian Life: The 2nd Coming of Christ is a Purifying Hope", (Desember, 2008), diakses pada 5 November 2019, http://storage.cloversites.com/journeythruthebiblesundayschoolclass/documents/1 Thess04-1.pdf

Schultz, John, "Commentary To First Thessalonians", (2003): 23, diakses 27 Oktober, 2017, http://www.bible-commentaries.com/source/johnschultz/BC_1Thessalonians.pdf

Serkarrini, Loveria, "Faktor-Faktor yang Berhubungan Dengan Perilaku Seksual Remaja di SMK Kesehatan di Kab. Bogor”, Universitas Indonesia; Depok, 2012

Subagyo, A. Bambang, Pengantar Riset Kuantitatif dan Kualitatif, Bandung: Kalam Hidup, 2004

Sugiyono, Metode Penelitian Pendidikan, Bandung: Alfabeta, 2010

Verhoef, Eduard, "1 Thessalonians 4:1-8: The Thessalonians should live a holy life", Maartensdijk, The Netherlands:2007

Wardani, Dayne Trikora, "Perkembangan dan Seksualitas Remaja”, Vol 17, No 3 (2012): 187, diakses 24 November, 2017, https://ejournal.kemsos.go.id/index.php/Sosioinforma/article/view/84 